\title{
A Summary of the History of the Caddo People
}

Frank F. Schambach

Unknown

Follow this and additional works at: https://scholarworks.sfasu.edu/ita

Part of the American Material Culture Commons, Archaeological Anthropology Commons, Environmental Studies Commons, Other American Studies Commons, Other Arts and Humanities Commons, Other History of Art, Architecture, and Archaeology Commons, and the United States History Commons

Tell us how this article helped you.

This Article is brought to you for free and open access by the Center for Regional Heritage Research at SFA ScholarWorks. It has been accepted for inclusion in Index of Texas Archaeology: Open Access Gray Literature from the Lone Star State by an authorized editor of SFA ScholarWorks. For more information, please contact cdsscholarworks@sfasu.edu. 


\section{A Summary of the History of the Caddo People}

Creative Commons License

(c) (i) (8)

This work is licensed under a Creative Commons Attribution-NonCommercial 4.0 International License 


\title{
A SUMMARY OF THE HISTORY OF THE CADDO PEOPLE*
}

\author{
by
}

\section{Frank F. Schambach}

I am pleased and very honored that you have invited me here today to tell you something about the past of the Caddo people as it is known to archaeologists. This is a subject that has been both my occupation and my major preoccupation for more than 25 years. The story that I and other archaeologists have been piecing together over many years is long, complex, and endlessly fascinating. It is a heritage that anyone could be proud of. Let me give you some of the highlights.

The story began over 11,500 years ago--or about 9,500 B.C.--when the first people arrived in the historic Caddo territory of Northwest Louisiana, Southwest Arkansas, East Texas, and Southeast Oklahoma. There were not many of them, perhaps only a hundred or so in this whole area at first. And the world they lived in was very different from the world today. It was cold, about like northern Maine or northern Michigan today, with forests of spruce and birch, because the Ice Age was still going on. They were probably dressed like Eskimos in carefully sewn parkas, trousers, and boots. We know this because many of the stone tools they left behind are tools for preparing hides and for making the bone needles necessary to sew them into clothing. They probably lived in skin tepees like those of the historic Plains Indians, but smaller, because they did not have horses to carry their gear from place to place. They did have dogs and they probably trained them to work as pack animals.

These earliest people were superb big game hunters who must have lived mainly on meat, the way many Indian people still do in Alaska and Canada, because there were not many plant foods in the Caddo country at that time, other than a few berries. Big game must have been very plentiful.

\footnotetext{
* This paper was presented at Robeline, Louisiana, June 27, 1992, at a Caddo Adais convocation.
} 
Fossil bones that have been collected from gravel bars on the Red River tell us that the big game available in the Caddo country back then included many lce Age animals that are now extinct in North America, or in this part of North America: the elephant-like mastodon, the giant ground sloth, camels, grizzly bears, elk, giant Ice Age bison and beaver, and a now extinct North American form of the horse. There were also deer and all the other smaller game animals that we have today-animals that survived the ending of the Ice Age while the big game did not.

The weapon these hunters used to kill the big animals of the Ice Age was the spear thrower or "atlall" with which a man could hurl a spear with the tremendous force needed to penetrate their thick hides. This weapon was still being used by Indian people living along the Gulf Coast when the Spaniards arrived in the 1500 s; it was also being used by the Aztec Indian people of Mexico, who called it the "atlatl."

The bow and arrow would not appear in North America until almost 10,000 years had passed. Small game was killed with hardwood throwing sticks or non-returning boomerangs identical to those used by the native people of Australia in historic times. Pieces of several of these have been found at a 10,000 year old camp site that is now at the bottom of a lake in Florida, so there is no doubt that this weapon was used by the earlicst American Indians.

These earliest people, whom archaeologists call the Paleoindians, probably lived very well, and probably would have continued to live as big game hunters, as their ancestors had done for tens of thousands of years before them, if they had not run into a major environmental problem. That problem was exactly the same problem we all fear today--the problem of global warming-and for them it became a reality. Between 8000 B.C. and 4500 B.C. the elimate gradually warmed until it finally became about two degrees Fahrenheit hotter year round than it is today. So there werc those expert Ice Age hunters facing the problem of learning to live in a world that was warming, becoming atmost tropical, and a world in which most of the Ice Age animals they depended upon were 
becoming extinct. This was a very difficult time for people everywhere in the world, particularly the 1000 years between 8000 B.C. and 7000 B.C., when populations seem to have gotten very low. It was probably a time of starvation and desperation for the early Indians.

But by 7000 B.C. there was a comeback. People had evidently learned how to supplement their meat diets with the nuts, seeds, fish, and shellfish that were so important in the diets of most North American Indian peoples at the time of European contact.

By this time there were probably a thousand or so people living in the Caddo country, and--for the first time--the tools and weapons of the people here, which archaeologists call the San Patrice culture, are somewhat different from those found in surrounding areas. Archaeologists are not certain about this because it is hard to be certain about anything that happened 9,000 years ago, but it is possible--and I think it is quite likely--that the people who left behind the tools and weapons of the San Patrice culture were the earliest identifiable direct ancestors of the modern Caddo people. So, many of you here today may have a truly ancient connection with this part of the world.

In any case, from this time on the artifacts of the Caddo country differ more and more from those of surrounding areas, and there is no doubt that by 1000 B.C. the people living here were the ancestral Caddo people. And 2,000 years later--by A.D. 1000-Caddoan culture, as it existed at the time Columbus landed in North America, was fully formed.

\section{WHAT WAS PREHISTORIC CADDO CULTURE LIKE AS IT EXISTED IN FULL.} FLOWER BETWEEN A.D. 1000 AND A.D. 1541, THE YEAR THAT HERNANDO DE SOTO'S ARMY INVADED THE CADDO AREA?

The Caddo were numerous and prosperous famers who lived in small farmsteads that could be found throughout every major and minor river and stream valley in the Caddo area. Their major crop plants were corn, beans, and squash, domesticated thousands of 
years earlier in Mexico, as well as sunflower and other varieties of squash domesticated in eastern North America. Like all the peoples of eastern North America, they had no domestic animals other than the dog and--possibly--the turkey, so they hunted and fished for meat and hides.

Deer and bear were their most important game animals and they were great deer hunters. For example, at one Caddo site in the Red River Valley I found the antlers of over 1,000 deer--most of them big deer--in a single pile. Their main hunting weapon was the bow and arrow, a weapon that suddenly appeared in most parts of North America about A.D. 500. The Caddo made their bows from the Bois d'arc, or Osage orange, a tree that seems to have grown mainly in the Caddo tribal area in those days. Thus, they may have had a near monopoly on one of the best bow woods in the world. Judging from the performance of modern replicas, these Osage orange bows were only a fraction less efficient than modern compound bows. They had draw weights of up to 65 pounds and they could drive an arrow at 170 feet per second. That is why Caddo bows were much in demand and were an important trade item in the Southeast and on the Plains in the early historic period.

Although these bows meant that the Caddo were probably better armed than most people in North America in pre-Columbian times, they were remarkably unwarlike. The early historic Caddo described themselves as a peaceful people and the archaeological record backs them up on this. While most of the castern tribes became so obsessed with war, or so embroiled in it, that nearly everyone was living in fortified villages from A.D. 1200 on, the Caddo built no forts. Nor did they leave behind any other evidence of warfare. Evidently they had solved the problem that still afflicts almost everyone in the world today--the problem of how to get along with people in the next village, the next rribe, and the next nation without fighting with them. It would be wonderful if we could figure out how they did it. 
It was not that they did not know how to fight. When de Soto's army fought the Caddo in the Arkansas River Valley in 1541, and in the Red River Valley in 1542, the Spaniards declared them the fiercest fighters they had engaged anywhere in the Southeast, which included some very fierce fighters indeed. And in both battles the Spaniards were nearly defeated, despite their steel weapons and their horses.

Part of the secret of the Caddo people's ability to lead peaceful lives was probably their great ability as traders and manufacturers. I have already mentioned their trade in bows or bow wood. The other important item of Caddo trade--probably the most important--was salt. The Caddo country was known to people to the east in the Mississippi River valley as Naguatex, or the place of salt, because all of the important salt springs west of the Mississippi River were located in the Caddo area in Arkansas and Northwest Louisiana.

Thus the Caddo had a monopoly on salt and this was a critical monopoly because the traditional American Indian diet of corn, beans, and squash is a diet that actually requires salt. That sounds strange in this day and age when all of us get too much salt from all the processed foods we eat, and salt is definitely something we need to cut down on to avoid hypertension and heart disease. But the corn, bean, and squash diet is a diet very high in potassium, which increases the need for salt. Without extra salt, people on this diet become lethargic because their blood pressure becomes too low. In fact, it can become so low that gangrene develops in the feet and hands. Some 60 of deSoto's men succumbed to this condition because the Spaniards could not find salt as they marched from Florida to the Mississippi River. Only when they got to the Caddo country did their health improve for there they visited practically every Caddo salt factory. So the Caddo had a commodity that hundreds of thousands of people in the Mississippi River valley had to have and they became the first large scale manufacturers and traders in North America, making salt at dozens of sites in Arkansas and Louisiana. 
The prehistoric Caddo lived in large sturdy houses that were often more than 50 feet in diameter and had thatched roofs. Their summer houses had walls covered with thatch or cane mats so the air could circulate through for coolness. The walls of their winter houses were plastered with clay for warmth. Around A.D. 1000 when the Caddo first started building these houses they were as comfortable and sophisticated as any houses in the world.

The prehistoric Caddo were great potters, perhaps the best in eastern North America. By A.D. 1000, when the average European was still eating off a slab of wood, the average Caddo had bottles, bowls and platters, and cooking pots holding 7 to 15 gallons. The best Caddo pots have highly polished surfaces and are decorated with intricate engraved or incised designs. Evidently this pottery was in demand among non-Caddo tribes in the Mississippi River valley because many Caddo pots found their way into that area in prehistoric times--one more important item in the Caddo trade network. Many more have now found their way into muscums and private collections around the world. And the best prehistoric Caddo pots command high prices on the art market--a fact that has, unfortunately, made the looting of prehistoric graves a lucrative occupation, as I'm sure you know. Hopefully the Indian burial protection laws that have now been passed in many states will finally put a stop to the grave robbing.

Although not many specimens have survived, there is good archaeological evidence that the prehistoric Caddo were also excellent basket makers. Like the other Southeastern tribes, they made their baskets of split cane, probably in many shapes and sizes and, to judge from the few surviving fragments, they were beautifully decorated.

Like most of the Southeastern tribes, the prehistoric Caddo were mound builders. They built many hundreds of mounds throughout their territory from A.D. $1000 \mathrm{on}$. We have records on more than 300 ) Caddo mounds from Southwest Arkansas alone, and about 100 in Northeast Texas. Very few of these mounds have been examined by modern archaeologists so there is probably a lot we do not know about them but they appear to be 
of two types: burial mounds which contain the graves of important priests and chiefs, and what we call temple mounds because they contain the remains of buildings that were apparently burned as part of religious ceremonies.

The largest Caddo mound is a temple mound near Garland, Arkansas, that is over 600 feet long, 300 feet wide and about 35 feet high, which makes it one of the largest mounds in North America. It was probably begun about A.D. 1400 and was probably still in use in 1542 when deSoto's army entered the Red River valley. It was probably the central meeting place or "ceremonial center" for the great Caddo province that the Spaniards found there. The place where it stands has been called Chakanina prairie from time immemorial. Chakanina is a Caddo term that experts in the Caddo language interpret as meaning "place where tears are shed" or "place of crying." This name seems to relate to the ancient Caddo custom (first noted by the Spaniards in 1541) of weeping when greeting people on formal occasions. If Caddo mounds were in fact central meeting places for people who lived on small farms scattered over the countryside, then the ancient name for such places might well have been "Chakanina," the place where tears are shed.

In 1541 when the Spaniards arrived, every place in the Caddo country had, of course, a Caddo name but almost all of those names are gone now, like the people who bestowed them. This is sad, but it is also fitting, and quite remarkable, that one of the few that has survived--the name of this place--is associated with the most important monument of the Caddo people. 